\title{
Rencontre avec Antonio Diaz-Florian, metteur en scène du Marchand de Venise, et François-Xavier Lecour (Théâtre de l'Épée de Bois)
}

\section{(2) OpenEdition}

\section{Journals}

Édition électronique

URL : http://journals.openedition.org/shakespeare/1243

DOI : $10.4000 /$ shakespeare. 1243

ISSN : 2271-6424

Éditeur

Société Française Shakespeare

Édition imprimée

Date de publication : 1 novembre 1992

Pagination : 171-172

Référence électronique

« Rencontre avec Antonio Diaz-Florian, metteur en scène du Marchand de Venise, et François-Xavier Lecour (Théâtre de l'Épée de Bois) », Actes des congrès de la Société française Shakespeare [En ligne], 10 | 1992, mis en ligne le 01 janvier 2007, consulté le 02 mai 2019. URL : http:// journals.openedition.org/shakespeare/1243; DOI : 10.4000/shakespeare.1243

Ce document a été généré automatiquement le 2 mai 2019

(c) SFS 
Rencontre avec Antonio DiazFlorian, metteur en scène $\mathrm{du}$ Marchand de Venise, et FrançoisXavier Lecour (Théâtre de l'Épée de Bois) 